\title{
Entre a reificação da mulher e a emancipação feminina: algumas contradições de um cronista de viagens brasileiro-lusitano (Oscar Leal, 1886-1895)
}

Francisco das Neves Alves (FURG)

https://orcid.org/0000-0002-8349-3300

Isabel Lousada (CICS.NOVA) - Centro Interdisciplinar de Ciências

Sociais da Universidade Nova de Lisboa

https://orcid.org/0000-0002-7652-8544

\section{Resumo:}

Oscar Leal foi um escritor brasileiro-lusitano que desenvolveu sua carreira literária na virada do século XIX ao XX, dedicando significativa parte de sua produção intelectual à literatura de viagem. Sob uma óptica civilizatória e eurocêntrica, em suas narrativas prevalecia a tradicional constituição do olhar sobre o outro, com ênfase para o inusitado, o diferente e o pitoresco. No que tange ao gênero feminino, o autor lançava um olhar dúbio e contraditório, pois de um lado empregava um tratamento que coisificava a mulher e, de outro, dizia-se um veemente propugnador da emancipação feminina. A abordagem dessa dicotômica visão constitui o objetivo deste trabalho.

Palavras-chave: Oscar Leal; literatura de viagem; reificação da mulher; emancipação feminina

\section{Abstract:}

\section{Between women's reification and female emancipation: some contradictions of a brazilian-lusitanian travel chronicler (Oscar Leal, 1886-1895)}

Oscar Leal was a Brazilian-Portuguese writer who developed his literary career at the turn of the 20th century, dedicating a significant part of his intellectual work to travel literature. From a civilizing and Eurocentric perspective, in his narratives the traditional composition of human behavior critique prevailed, with an emphasis on the unusual, the different and the picturesque. With regards to the female gender, the author casts a dubious

* Professor Titular da Universidade Federal do Rio Grande - FURG. E-mail: franciscodasnevesalves@ gmail.com

** Investigadora Auxiliar da NOVAFCSH, integrada no CICSNOVA: Centro Interdisciplinar de Cièncias Sociais, da Universidade Nova de Lisboa. E-mail: isabel.lousada@fcsh.unl.pt 
and contradictory glance, because on the one hand he used a treatment that objectified women and, on the other, he said he was a strong proponent of female emancipation. The approach of this dichotomous view is the objective of this work.

Keywords: Oscar Leal; travel literature; woman's reification; female emancipation.

Ao longo do século XIX, houve um intenso intercâmbio cultural entre a intelectualidade portuguesa e a brasileira. Nesse contexto esteve Oscar Leal (1862-1910), que nasceu no Rio de Janeiro, mas, de família portuguesa, e que em seguida deslocou-se para terras lusas, onde realizou seus estudos na cidade de Funchal. Sua formação educacional e acadêmica foi empreendida no eixo Brasil Portugal, vindo a formar-se em cirurgia craniana e dentária (BLAKE, 1900, v. 6, p. 339; e SILVA, 1894, p. 131). Apresentava-se como especialista em doenças da boca, dentes e correções das deformidades nasais e como diplomado na América e Escola Médica de Lisboa (LEAL, 1904, p. 1). Empreendeu inúmeras viagens, notadamente pelos sertões brasileiros, percorrendo o país entre as décadas de 1880 e 1890, em permanências entremeadas por retornos a Portugal. A partir de 1894, fixou-se definitivamente em Lisboa, estabelecendo residência e "gozando os melhores créditos como clínico, notabilizando-se nas especialidades a que se dedicou" vinculadas a "doenças de boca, dentes e correção das fossas nasais" (PEREIRA \& RODRIGUES, 1909, p. 98), montando escritório na capital portuguesa, onde permaneceu até o seu falecimento.

Ao lado de suas práticas profissionais, desenvolvidas muitas vezes de maneira itinerante, à medida que empreendia viagens por várias partes do mundo, Oscar Leal promoveu uma significativa produção intelectual. Sua obra inclui variados títulos, dentre os quais podem ser destacados: os versos Flores de abril e Flores de maio; os romances Uma mulher galante e Zelia: amores de uma brasileira; o esboço biográfico Brasileiros ilustres (perfis contemporâneos); a história ligeira $O$ Manoel de Soiza; a novela $A$ filha do miserável; a opereta $P a-$ lomita; os discursos $A$ questão do abade; a conferência As regióes de terra e água; os apontamentos gramaticais $A$ linguagem dos Cocamas; a novela naturalista $O$ parteiro; a crítica Dentistas e "dentistas"; e o romance histórico Um marinheiro do século XV (BLAKE, 1900, v. 6, p. 339-340; e SILVA, 1894, p. 131). Ainda aparecem como de sua autoria Um conto do sertão; Excursões; e Clínica odontológica.

Especificamente no que tange à literatura de viagem, o autor publicou as impressões de seu itinerário na Europa no livro Do Tejo à Paris, de 1894 e o relato Através da Europa e da África (viagens), de 1901. Já no que tange a suas permanências e deslocamentos no Brasil, escreveu os livros Viagem ao centro do Brasil (impressões), editado em Lisboa, no ano de 1886; Viagem às terras goianas (Brasil central), publicado igualmente em Lisboa, em 1892; Contos do meu tempo, levado à publicidade em Recife, no ano de 1893, trazendo textos em prosa e verso, além de um segmento voltado às excursões; e Viagem a um país de selvagens, publicado em prelos lisbonenses, em 1895. Além disso, publicou $O$ Amazonas, conferência realizada na Sociedade de Geografia de Lisboa em novembro de 1894 e editada no mesmo ano.

Ao longo de seus itinerários e permanências, estabeleceu contato com vários repre- 
sentantes do mundo intelectual, mormente no contexto luso-brasileiro. A partir de sua obra e reconhecimento, militou junto a várias instituições acadêmico-culturais. Nessa linha, foi membro da Sociedade de História Natural de Madri; das Sociedades de Geografia de Madri, Nova York, Rio de Janeiro e Lisboa; da Sociedade Espanhola de História Natural; dos Institutos Históricos de São Paulo e Bahia; da Arcádia Americana do Pará; do Grêmio Literário da Bahia; da Academia Literária do Real Instituto de Lisboa; da Sociedade dos Homens de Letras do Porto. Além dos livros, também teve destacado papel como editor e colaborador junto à imprensa periódica, meio pelo qual também divulgou suas impressões de viagem. Foi diretor dos jornais Antessala, $O$ Correio dos Clubes, Dentários, $O$ Viajante e $O$ Tributo às Letras. Também esteve à frente da revista ilustrada noticiosa, crítica, literária, biográfica e bibliográfica A Madrugada, editada em Lisboa, entre 1894 e 1896 e da Revista de Lisboa, publicada entre 1901 e 1908 (LEAL, 1904, p. 1 e 66; PEREIRA \& RODRIGUES, 1909, p. 98 e BLAKE, 1900, v. 6, p. 239).

A realização de viagens foi uma prática constante na existência de Oscar Leal, tendo percorrido várias regiões portuguesas, brasileiras e africanas, e visitado Paraguai, Bolívia, Argentina, Uruguai, França, Espanha, Itália, Suíça e Inglaterra. Nesse sentido, além dos deslocamentos entre Portugal e Brasil à época de sua formação acadêmica e na prática de sua profissão, viajou "muito, não só pelo prazer de visitar os países estrangeiros, mas com o propósito de estudar o que de mais notável" poderia encontrar "no tratamento das doenças" que constituíam "a sua especialidade". Por meio de tais viagens, "adquiriu magníficas coleções e reuniu muitas curiosidades dignas de menção" (PEREIRA \& RODRIGUES, 1909, p.
98). De suas tantas excursões por diferentes continentes resultaram vários relatos que estiveram a contento com a prática de uma literatura de viagem.

Em seus relatos de viagem sobre o Brasil, Oscar Leal manteve em sua escritura vários elementos que vinham sendo reproduzidos na literatura de viagem ao longo dos séculos anteriores, desde as primeiras incursões às terras brasileiras. Por literatura de viagem pode-se entender um "subgênero literário que se mantém vivo do século XV ao final do século XIX, cujos textos, de caráter compósito, entrecruzam Literatura com História e Antropologia", vindo buscar na "viagem real ou imaginária temas, motivos e formas". Nesse quadro a viagem aparece como a descrição do deslocamento e os destaques daquilo que "pareceu digno de registro: a descrição da terra, fauna, flora, minerais, usos, costumes, crenças e formas de organização dos povos, comércio, organização militar, ciências e artes", assim "como os seus enquadramentos antropológicos, históricos e sociais" (CRISTÓvÃO, 2002, p. 35).

Por mais que tivesse nascido no Brasil e insistisse em se dizer brasileiro, Oscar Leal se comportava como um cidadão europeu, mormente ao lançar suas visões sobre o Brasil, afinal, Portugal era a "pátria do seu espírito" (TORRESÃO, 1898, p. 1). Tal perspectiva ia além da nacionalidade, uma vez que perpassava pela óptica que o escritor lançava sobre o Brasil, vindo a estabelecer uma criação em que lançava um olhar sobre o "outro", ou seja, considerava-se como o "civilizado" que observava aquele que apontava como "atrasado", ou até mesmo "selvagem". Nessa linha, Leal, como viageiro e escritor conferiu a si mesmo uma missão civilizatória, promovendo estudos que poderiam ter serventia no caminho do progresso para o país tropical, aproximando-o 
da "civilização" europeia, tanto que considerava que tal atuação constituiria um verdadeiro "serviço prestado" ao Brasil. Tal olhar era também influenciado por alguns pressupostos que adotava como padrões para suas vivências, notadamente o cientificismo, o republicanismo, o abolicionismo e o anticlericalismo, estes três últimos traziam um manifesto desacordo para com o Brasil que visitou durante a maior parte de suas viagens, monárquico, escravista e mantenedor de uma religião oficial.

Tais marcas do pensamento de Oscar Leal tiveram uma indelével influência nos escritos que estabeleceu a respeito do Brasil, onde via enormes potencialidades econômicas, mas também localizava em alguns dos hábitos e costumes dos brasileiros as razões que atravancavam os rumos em direção à elevação do país à categoria dos ditos civilizados. A partir dos "relatos de viagem" torna-se possível "a experiência do estranho, do outro", trazendo também consigo "a formação de novos horizontes de pensamento e imaginação" (AUGUSTIN, 2009, p. 20-21). Dessa maneira, "a literatura de viagem estimulou o fascínio pelo outro", em um quadro pelo qual "viajar era um ato paciente de observação, de obter informações e aprender" (ASSUNÇÃO, 2016, p. 162). Buscava-se então, "a especificidade das diferenças, ou, pelo menos, para refletir sobre elas e manifestar a complexidade de reações que essa dualidade de éticas e mesmo de estéticas implica" (SEIXO, 1996, p. 123).

Nem sempre o viajante "quer conhecer, e sim comprovar", como no caso de "verificar se os códigos de conduta" dos nativos "se ajustam ao modelo exemplar do estrangeiro". Assim, "da inofensiva viagem da curiosidade" ruma-se "para um encontro entre duas culturas que progressivamente adquire as características de um conflito" trava- do entre a civilização e a selvageria. Esse último estágio era associado a "uma ideia central" de "ociosidade anárquica", uma vez que, dentre seus integrantes emergiria "o esboço do ser humano incompleto", ou seja, aquele que deixava de estabelecer "contatos sociais", não possuindo leis ou deliberando em praça pública, além de não semear os campos ou morar em cidades. Nesse sentido, eles passavam "automaticamente a carecer dos atributos que tipificam o civilizado", sendo observados como "indolentes", já que só aproveitavam-se dos "dons da natureza para saciar suas necessidades diárias" (GIUCCI, 1992, p. 26-27).

Surgia assim "um Brasil pensado por outros", pois "as obras configuradas pelos viajantes engendram uma história de pontos de vista, de distâncias entre modos de observação, de triangulações do olhar". Nesse quadro, "a vida e a paisagem" são observadas a partir da "espessa camada da representação", pela qual se "evidenciam versões mais do que fatos". Em "sua origem, as imagens elaboradas pelos viajantes participam da construção da identidade europeia", apontando os "modos como as culturas se olham e olham as outras, como estabelecem igualdades e desigualdades, como imaginam semelhanças e diferenças, como conformam o mesmo e o outro" (BELLUZZO, 1996, p. 10). Assim, "os depoimentos dos viajantes se constituem de representações, reinvenções de realidades, produzidas a partir da visão de um sujeito". Trazem consigo imagens que se apresentam "em representações do real, elaboradas a partir de componentes ideológicos de pessoas dotadas de equipamentos culturais próprios", as quais "trazem um patrimônio anterior que condiciona o modo de observar e entender o empírico". Tais "representações expressam o contexto em que se formaram e o imaginário social 
da sociedade em que seus autores viviam" (REICHEL, 1999, p. 59).

0 fator motor da literatura de viagem vincula-se ao fato de que a excursão é "impulsionada pelo desejo de conhecimento e de aventura", de modo que a escrita dela oriunda "é sempre seletiva", pois "fala-se do 'notável', do 'memorável', do 'pitoresco', do diferente, do que se destaca pela sua própria natureza, impondo-se ao observador e exigindo ser registrado" (RITA, 2007, p. 272). Oscar Leal observou atentamente esses caráteres "pitorescos" do Brasil e dos brasileiros, olhando-os por vezes com certa admiração, mas, muitas vezes, com descrédito, menoscabo e preconceito. Apesar de não ser o foco mais importante de sua obra, esse olhar do autor também se voltou ao feminino. Tal óptica desenvolveu-se em dois sentidos que traziam certas contradições entre si, pois, por um lado, ele fazia descrições sobre as mulheres calcadas em seus atributos físicos e voltados a uma coisificação para com elas; e de outro, intentava mostrar-se como um ardoroso defensor da emancipação feminina. Essa dubiedade ficava bem expressa em três de seus livros nos quais abordava a sociedade brasileira: Viagem ao centro do Brasil, Viagem às terras goianas e Viagem a um país de selvagens.

0 primeiro livro escrito por Leal acerca do Brasil, Viagem ao centro do Brasil (impressões), tratava de uma excursão feita pelos sertões do país tropical entre 1884 e 1885, partindo da capital imperial e passando pelas províncias de São Paulo e Minas Gerais até chegar ao Brasil central, onde mais tempo permaneceu e depois estabeleceu o mesmo trajeto no retorno. Nesse relato, em vários momentos apareceu o olhar calcado na reificação da mulher, no escopo de confirmar a característica de conquistador que por várias vezes atribuíra a si mesmo, por meio de textos autobiográficos (LEAL, 1893). Uma das primeiras deu-se na descrição de sua estada na localidade de Franca, em São Paulo, quando colocava o encontro com uma mulher na mesma categoria do divertimento no convívio com um amigo. Nessa linha, dizia que "à noite fui jogar uma partida de bilhar com o Gaspar que depois de me ganhar, apresentou-me a certa deidade do lugar cuja alcunha já havia ouvido repetir mui longe dali" (LEAL, 1886, p. 48).

0 fato de julgar as mulheres pela aparência chegou a levar o escritor a quase cometer uma grave afronta, quando, ao sair de Vila de Santa Rita do Paraíso em direção ao Rio Grande, dirigia-se à fazenda do barão da Ponte Alta, na qual iria pedir pousada. Dizendo-se sabedor que o proprietário não se encontrava, narrou que, "depois de bater palmas por duas ou três vezes apareceu-me uma mulher trajando vestido de chita encardida, os cabelos em desalinho, os pés sem meias, ocultos nas pontas por umas tamancas de sola", com "uma criança nos braços". Diante disso, Leal calculara que se tratava, "sem dúvida", de "uma mucama ou criada da casa”, mas se surpreendia por ser a própria baronesa. Para compensar, depois de receber a guarida, comentou que reconhecera "na baronesa um hospitaleiro coração, fugindo sempre quanto pode a quaisquer formalidades luxuosas que lhe não estão a caráter" (LEAL, 1886, p. 60).

Como em vários momentos de suas narrativas, Oscar Leal por vezes mostrava-se cansado nas vivências interioranas e demonstrava saudades da vida boêmia nas grandes cidades. Em um desses casos, ressaltava os convívios que estava perdendo nas noitadas, com diversões que incluíam lugares da moda, bebida e o desfrute de uma "dulcineia". Nesse sentido afirmava que, "se num destes momentos pudesse deixar aque- 
la espelunca e entrar no Stad de Coblenz do Rocio, na Maison Moderne ou no Café Brasil!", vindo a "pregar um pontapé em toda aquela traquitana de viagem e entrar num fáeton mais uma dulcineia e gritar ao cocheiro: Botafogo, e depois ver o champanhe espumar como o elixir da ventura!". (LEAL, 1886, p. 67-68).

0 "conquistador" Leal voltava à baila em outra passagem, no Arraial de Dourados, lugar em que foi acometido por terrível coceira advinda do ataque de carrapatos, vindo a recolher-se "a um repartimento, arrancando brutalmente a roupa para fora do corpo" e, para sua surpresa, apareceu "uma raparigona acaboclada" que "veio se oferecer para me catar e de costas viradas dispus-me à operação". Como "a rapariga era nova e simpática e como nos achávamos a sós, gostei do final da festa". Ainda que não esmiuçasse os temas de alcova, voltou a referir-se à referida moça, ao dizer que, "antes de partirmos a mocetona da véspera veio despedir-se, trazendo-me de presente dois jenipapos", ele queria "retribuir com um beijo, mas o diabo do tio ali se achava na ocasião" (LEAL, 1886, p. 71-72).

A caminho de Paracatu, em Minas Gerais, Leal voltava à descrição de uma figura feminina, demonstrando que a atração por "caboclas" tinha um limite vinculado fortemente à faixa etária. Descrevia assim a chegada de "uma velha cabocla com feições de múmia, o nariz profundamente deprimido na base, os cabelos soltos como se nunca conhecessem um pente", além de estar "completamente nua da cintura para cima, deixando ver uns peitos caídos e mirrados", bem como vestia uma "saia, cuja fazenda impossível era o saber-se a que espécie pertencera, estava em tiras e farrapos, ficando quase à mostra as partes que o pudor e o recato mandam ocultar" (LEAL, 1886, p. 80).
Ao chegar nas localidades, Oscar Leal tinha um hábito de qualificar as representantes do sexo feminino pela aparência física, assim, sobre Paracatu dizia que "o belo sexo é bastante amável mas vi poucas caras sofríveis" (LEAL, 1886, p. 85). Na mesma localidade, o escritor narrava a visita de um indivíduo, a partir da qual se desencadeava uma rocambolesca historieta, na qual estaria a aflorar tudo que poderia se propalar como a astúcia e o charme do conquistador que, após ganhar seu prêmio, escafedia-se rapidamente, em "aventura" digna de registro em seu caderninho:

Uma vez sós, disse-lhe ser todo ouvidos.

Tratava-se nada mais nada menos, de que de um casamento, em que devia ser eu o noivo, e a noiva uma mocetona dos seus trinta janeiros.

Apaixonada como se achava e tendo para ela a amizade de irmão, prometera-lhe vir falarme a respeito. Pelo que se vê este padrinho queria representar para comigo o papel que me cabia, se porventura me sentisse igualmente apaixonado.

Pro virite parte respondi-lhe que nessa mesma noite ela teria a resposta.

Parti, pois, um pouco fora da hora convencionada. Encontrei-a em casa, e ao ver-me mostrou-se admirada como se não me esperasse. Espanto nenhum de mim se apoderou.

Macaco velho, e discípulo favorito de Cupido estava costumado a estas cenas.

Puxei de uma cadeira e sentei-me a seu lado com todo o acatamento, parecendo-me perceber nos seus olhos uns vislumbres de satisfação mal demonstrada. 0 meu sôfrego olhar pairava no acaso e embora mal, julguei que o delírio da paixão havia chegado ao zênite do deslumbramento.

A natureza, porém, fugia de pagar o seu tributo aos gozos do mais adorável de todos os deuses. 
A pequena alcova era alumiada pela luz de uma vela, que se coava dúbia e tímida, através do fosco de um globo que estava sobre a mesa da sala.

Foi ela quem após alguns momentos de silêncio veio à fala. Os seus braços arquejantes e os olhos irradiando viveza e luz, diziam talvez mais do que todas as palavras de um vocabulário. (...)

Passada uma hora sumida em arroubos (...) e num instante em que a admirava nos seus arrebatamentos (...), batem à porta e entra 0 Sr. L., que não me conseguiu ver. (...)

Uma, duas horas, até que num momento feliz pus-me a panos, salvo como um pero e aspirando mais livre ar.

Foi uma aventura extravagante que entrava sem dúvida para o meu canhenho. (LEAL, 1886 , p. 86-88)

Em pleno meio rural, a caminho de Formosa, em Goiás, ele encontrou a "mulher do rancheiro, que era uma cabocla rechonchuda" e confundiu-a com um vendedor. Pouco depois, ele afirmava que "estava louco por chegar quanto antes a Formosa, a terra das raparigas bonitas" (LEAL, 1886, p. 94-95). Já em nesta localidade, descrevia um hábito estranho entre as jovens locais, afirmando que, "nesta cidade como tive ocasião de conhecer, há raparigas que apenas mocinhas de 12 ou 14 primaveras, abandonam a casa paterna, acompanhando hábeis sedutores, que as largam logo sem pena nem dó no mundo equívoco". Comentava que esta seria "a maior glória que aspiram, para mais tarde poderem dizer que as suas honras ficaram com fulano ou sicrano, moço rico e de posição, cometa, negociante ou inverneiro, dono de tantos lotes de burros ou de tantas cabeças de gado!". Ainda sobre tais moças, destacava que "detestam o casamento e muitas daquelas que chegam a casar, gaitam os maridos, trocando-os por amantes ou mesmo pela vida alegre". Finalmente dizia que elas eram “de um gênio terrível, e desgraçado daquele que cai nas unhas" delas; para arrematar com a informação de que "a prostituição manifesta-se de um modo espantoso" naquele local (LEAL, 1886, p. 102-103). Finalmente, já no retorno da viagem, a caminho de Uberaba, em Minas Gerais, voltava a descrever uma mulher a partir de sua aparência, falando de uma figura feminina que se encontrava "deitada numa rede com as pernas à mostra, sem lhe dar cuidado quem se aproximava", explicitando que "uns fusos comparados com aquelas pernas pareceriam obesos" (LEAL, 1886, p. 157).

Já o livro Viagem a um país de selvagens se referia a outra excursão de Oscar Leal, esta empreendida no ano de 1886, partindo do Pará pela região amazônica, e nela ocorreriam outros comentários a respeito das mulheres sertanejas e índias. Logo no início do deslocamento, ele viajava por rio a caminho da localidade paraense de Cametá e se referia a uma estranha crença entre os locais, mormente as mulheres, que vislumbrava a possibilidade de vê-las nuas. Apesar de considerar um grande contrassenso, o escritor não deixava de mostrar suas intenções cúpidas:

De instante a instante, do parapeito de popa eu deitava o binóculo para algumas habitações que orlam com grandes intervalos as margens do rio, onde mulheres, homens e crianças acudiam a ver passar o vapor. Mais de uma vez notei que, ao assestar-lhes o binóculo, as mulheres tão somente corriam a esconder-se, ou caíam por terra, aconchegando-se umas nas outras. Intrigado com isto, procurei saber o motivo, e foi com pasmo que ouvi um passageiro afirmar ser crença entre essa gente que o binóculo nos faz vê-las de pernas para o ar, descobrindo à vista todas as partes do corpo!

0 riso que tal explicação me causou fezme de novo entregar ao curioso passatem- 
po, e, por causa da teima, vi-me dentro em pouco coberto de invectivas e insultos com que as mulheres de terra me mimoseavam, furiosas todas contra mim e, sobretudo, contra o uso de tal objeto, que, infelizmente, não possuía as famosas virtudes que lhe atribuíam. (LEAL, 1895, p. 21-22).

Já em Cametá, abordando "usos e considerações" sobre o local, destacava que a localidade era "a terra das procissões", tanto que no primeiro mês que ali estivera observou pelo menos quatro. Mesmo diante da solenidade religiosa, o autor não deixava de tecer comentários sobre o feminino, dizendo que em tais "ocasiões tudo que é mulher e devota de mediana estirpe sai à rua e no acompanhamento notam-se algumas trajando vestidos de gosto legendário e carregando sobre o peito e nos cabelos grossos cordões e ornatos de outro maciço". Na mesma localidade, Leal descreveu as "reuniões dançantes" das quais participou, momento em que teve "ensejo de conhecer mais a fundo a sociedade cametaense", explicando que "as moças da cidade trajam regularmente com gosto fácil, sem rigor, têm mesmo alguma desenvoltura" (LEAL, 1895, p. 36 e 38).

Ainda acerca das jovens cametaenses comentava que "quanto mais pobres, tanto mais pretenciosas, preferindo sempre cavalheiros que as lisonjeiem", uma vez que, "a primeira vez que se lhes tece um elogio qualquer quanto à formosura, respondem estudadamente com alguma rigidez, fingindo-se ofendidas, mas deixando as mais das vezes perceber o prazer que sentem pela amabilidade" manifestando-se "alegres desde que se lhes garanta sinceridade no louvor". A análise do feminino permanecia, com a constatação de que lhe fora dito "que em outros tempos Cametá era fértil em jovens belas e formosas" e, diante disso, dizia que percorrera o município, tendo "ensejo de notar a fundo tudo quanto possa interessar a tal respeito". Também relatava que fora da cidade vira "Mayayas belas e formosas, morenas de formas deslumbrantes e cujo acanhamento e modéstia lhes dá, a meus olhos, maior realce, tornando-as encantadoras", demarcando ainda que, "durante as festas em Cametá, elas são a alma da alegria que muitas vezes se prolonga durante dias e noites seguidas" (LEAL, 1895, p. 38-39). 0 encantamento do escritor foi tão significativo que ele deu o nome de Mayaya a uma personagem de um dos textos de seu livro Contos do meu tempo. 0 termo maiaia se refere a um substantivo feminino que designa moça indígena das margens do Rio Tocantins.

Leal também fazia referência a festividades realizadas na Vila de Mocajuba, no Pará, demarcando que entre os tantos atrativos, estavam as mulheres ao citar que lá havia "música, danças, foguetes e, sobretudo, muita alegria e muita moça bonita (LEAL, 1895, p. 62). Já em outra localidade paraense, na Vila do Baião, descrevia as comemorações natalinas, referindo-se ao amplo movimento das pessoas que para ali acorriam, como o recebimento de grande número de romeiros. Em meio às festividades, descrevia uma moça local, em tom que era um misto de cobiça e jocosidade:

De súbito, uma cabocla moça e bela, carregada de fitas e adornos esquisitos, conquistando de um salto o centro do local em que tinha lugar o batuque, formava o solo, sendo o final da cantiga repetido como estribilho por dezenas de vozes acompanhadas de esgares e requebros, quedas e umbigadas, provocadas pelo entusiasmo e animação. Pouco a pouco me convenci estar, não na presença de uma estrela coreográfica, mas sim, diante de uma neurótica.

Era, na verdade, um tipo imponente, de cabelos cor de ônix, tez bronzeada, corpo esbelto, cheio de graça e de agilidade. 
No dançar, tinha ondulações de jiboia, movimentos provocantes, requebros de estontear o homem mais sério e sisudo, que ali se achasse.

Vergando-se às vezes, de cabeça pendida, o olhar enlanguescido, os cabelos a adejarem-lhe em volta do rosto, onde pairava um sorriso voluptuoso, lascivo, debochado, dirse-ia que tinha diante de mim um gênio epiléptico, uma Vênus histérica. (LEAL, 1895, p. 85-86)

Na mesma circunstância, o olhar avaliativo do escritor não poupou nem mesmo uma vendedora, destacando que "à ilharga do sítio, onde se realizava este clamoroso batuque, uma gorda mulherona, em estreito repartimento coberto por um teto de palhas, assentada junto de um braseiro, assava no espeto postas de pirarucu, que eram logo vendidas aos foliões". Mais tarde em uma reunião dançante, no mesmo local, tecia um comentário mais abrangente quanto à aparência do conjunto das mulheres da Vila: "então me foi dado ver que o belo sexo do Baião e suas imediações é bastante amável e sedutor, havendo alguns exemplares de sofrível beleza, e jovens de encantadores semblantes, em que a cor morena se ostentava em maioria" (LEAL, 1895, p. 86 e 88).

Em Viagem a um país de selvagens, o fulcro do livro era exatamente a experiência do autor entre os "selvagens" propriamente ditos, ou seja, os indígenas. Suas impressões deram-se em relação a uma tribo de apinajés, só que, ao invés do tradicional trabalho do naturalista, tecendo considerações de ordem etnológica e antropológica, Oscar Leal optou por uma abordagem romanesca e folhetinesca, na qual ficava evidente sua cobiça para com as indígenas. Desde o primeiro momento ele se mostrou profundamente interessado pela filha do cacique, Aygara, demonstrando-se surpreso quando este colocou as mulheres da tribo à sua disposição.
Não se mostrando de todo contrariado, o escritor relatava a realização de um verdadeiro concurso de beleza entre as índias, para escolher a sua preferida:

Ia-me, pois, despedir quando vi aproximarse de nós uma jovem índia muito clara cuja presença me deixou assombrado. Era na verdade uma rapariga selvagem como as outras que ali se achavam, mas eu nunca pudera antever como em uma mulher desta classe pudessem existir tantos atrativos e tantas graças, pelo que desde logo me foi dado conhecer. (...)

Aygara, tal era o seu nome, representava contar as suas quinze primaveras se bem que o seu físico tivesse chegado a elevado grau de desenvolvimento.

Aygara, aproximando-se mais, estendeu-me as mãos sorrindo-se como se uma satisfação enorme a abalasse profundamente.

Eu sentia então um desejo imenso de poder compreendê-la, de conhecer a sua língua, para ouvir a sua história que na realidade devia ser interessante se é que mal entendia o português. (...)

- Pois bem, grande cacique, disse afinal, manda vir à minha presença todas as donzelas da tua tribo. Quero escolher a que mais me agrade.

Quando havia de julgar que aos vinte e cinco anos de idade, na flor da vida, cheio de esperanças, em plena mocidade, teria de escolher noiva entre os selvagens.

Eu casar-me! (...)

Dentro em poucos momentos à frente do meu quiosque, como desde logo denominei a minha habitação, era invadida por um grupo de trinta índias novas e algumas belas, todas de cor bronzeada, destacando-se o vulto airoso e simpático da filha do cacique.

Que situação!

Isto me estava custando, mas afinal, decidime a passar no grupo uma minuciosa revista tomando a coisa por mero passatempo, po- 
rém, ao acercar-me delas, agradando-lhes com uma mimica especial, fui surpreendido com o barulho que fizeram em volta de mim, buscando todas quererem examinar o meu pince-nez e uma por uma não descansava enquanto o não sentava cada uma no seu nariz sem poder perceber qual o proveito a tirar do seu uso.

Aygara estava de todas a mais inquieta e não cessava de me fustigar para preferi-la.

Decididamente acabei por gostar da brincadeira e julgava tratar de um torneio de beleza, diante daquelas formas plásticas expostas a meus olhos e livres das bárbaras confecções das mais afamadas modistas do mundo.

Finalmente, para terminar com a exposição, pedi que se retirassem, que depois eu me entenderia com o cacique sobre a eleita do meu coração.

- Ora esta, disse a sós comigo. Querem que escolha companheira, que me case. Pois caso-me. É um fato muito natural.

E como ia achando até certa graça em tudo isto disse ainda:

- Caso-me até com dez mulheres se quiserem. Tenho coração para muito mais. (LEAL, 18895, p. 112 e 118-120)

Inevitavelmente a vencedora foi Aygara, vindo a ocorrer uma espécie de "cerimônia de casamento", segundo os costumes indígenas, terminada a qual, "as outras índias conduziram Aygara para a esteira estendida debaixo da minha maca, onde já me achava em atitude de descanso, retirando-se todas em seguida e deixando-nos em paz". Em conclusão, afirmava: "estávamos casados, segundo o uso índio bem entendido". Na narrativa não havia nenhum comentário sobre o ocorrido à noite, mas a partir daí o autor viria a descrever os mistérios que cercavam Aygara, descobrindo que sua mãe era branca e fora raptada pelos índios quando estava grávida de um homem pertencente à família poderosa de Goiás. Com isso, só aumentava o viés romanceado da historieta e demonstrava que, afinal, o civilizado Oscar não tinha se "casado" com uma selvagem, ao menos do ponto de vista étnico. Aos poucos, Leal passava a se desinteressar pela índia que aprendera a expressão "Meu amor" e não parava de repeti-la em todas as situações, além disso, ele descobriria que ela tinha uma predileção por comer gafanhotos, o que azedaria de vez o "casório" (LEAL, 1895 , p. 125).

Na continuidade, Oscar Leal viria a conhecer uma outra índia que, mais uma vez deixara-lhe dominado pelo desejo. Ainda que dissesse que suas intenções eram meramente platônicas, ficava uma outra impressão no ar, tanto que o autor usaria a expressão que bebera água da fonte até se fartar, ficando em suspenso a perspectiva se tal ato ocorrera no campo literal ou figurado. A formação do triângulo amoroso acabaria por desmanchar-se diante da reação de uma enciumada Aygara:

Como era um pouco tarde, partimos dali em direção à aldeia, quando nas suas proximidades vi assentada à oriental, junto à nascente dos Buritis, uma índia bastante nova, cujas formas divinais me chamaram a atenção.

Movido pela curiosidade, (...) soube que se chamava a formosa mulher - Cararay.

Esta palavra significava astúcia, segundo me explicou logo Aygara, prevenindo-me de que Cararay era pouco estimada das suas companheiras por ser mais esperta do que elas.

Mostrei desejos de ir até o sítio onde se achava e para isso fui tomando a devida direção, mas Aygara não me permitiu de forma alguma.

Sucedeu que, na manhã seguinte, ao dar o meu passeio matutino, aproximei-me da nascente e lá novamente a fui encontrar, como se tal encontro fosse de antemão combinado. 
Cararay soçobrava um púcaro de argila que ia encher.

Era na verdade um esplêndido tipo de mulher e eu não pude resistir ao desejo de ajudá-la a encher o cântaro com as cristalinas águas daquela poética e silenciosa fonte, rodeada de pequenas e copadas palmeiras, cujas copas ainda se apresentavam cobertas de reluzentes gotas de orvalho.

Como estávamos sós, tive de recorrer à mímica para que me compreendesse.

As minhas intenções diante daquele corpo esbelto e selvático eram todas puramente de admiração platônica.

Admirador em extremo das belezas indígenas, julgava-me fascinado por uns olhos como os de Cararay, sombreados de espessas pestanas negras a reluzirem num fundo bronzeado.

Encontrava nesta ocasião mais grandiosidade nas cenas dos bosques entre o pipitar das aves e os encantos desta vegetação tropical, do que se me achasse nos grandes salões, onde quase tudo sempre reluz o que é falso e mentiroso, fruto das sociedades corrompidas.

Cararay ria-se expressivamente ao contemplá-la e passava sobre as minhas as suas mãos bronzeadas com uma meiguice puramente selvagem, mas enternecedora.

Não querendo mais demorar-me ali, levei à boca um cabaço cheio de água fresca da fonte e bebi, bebi até fartar...

Ao erguer-me avistei Aygara, que corria em minha procura e que furiosa se mostrou por ver-me a sós com Cararay, a quem lançou uns olhares de ódio e de despeito. (LEAL, 1895, p. 140-141).

A "esposa" passou a mostrar-se plenamente vigilante, buscando manter a rival fora do alcance do "marido". Mais tarde, ela viria a queixar-se quanto à concorrente, ao que Oscar, como bom embromador, garantia-lhe que ele era "a preferida" e continua- ria amando-a, pois ela seria "a mais formosa de todas as mulheres desta tribo, de todas a mais sedutora". Além disso, fazia uma promessa que bem sabia que não iria cumprir, dizendo que iria "voltar pelo grande rio para novamente te ver e amar" (LEAL, 1895, p. 144-146). Nem ao imaginar uma versão romanceada, o autor abandonava a velhacaria, fazendo elogios desmesurados e um juramento que iria deixar de lado, tanto que, em seguida, abandonou a tribo deixando para trás sua chorosa "esposa”. Fosse por um gosto particular, ou ainda para atrair um público leitor masculino, Leal chegou a estampar a imagem das duas índias com quem teria acontecido o triângulo amoroso. Era a plena coisificação do feminino.
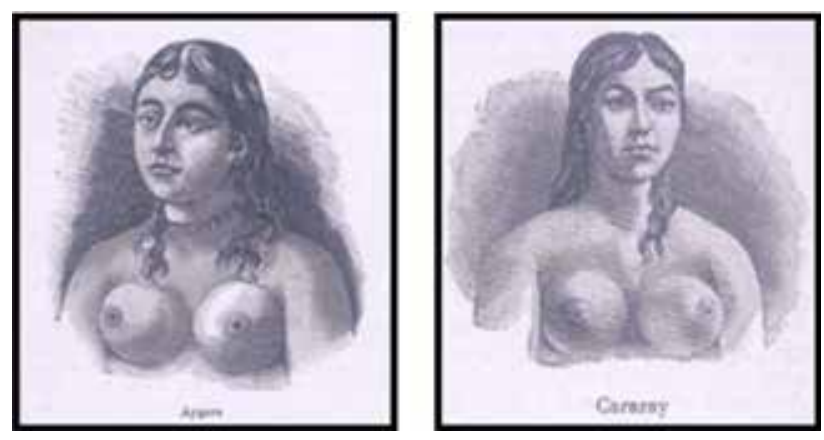

Este constante reificar do feminino presente na obra de Oscar Leal se contrapunha frontalmente a um elemento constitutivo bastante recorrente ao seu discurso voltado à intransigente defesa da emancipação das mulheres. Seu pensamento progressista, cientificista e libertário se coadunava com essa perspectiva de pensar em um novo papel social para a mulher. Tal perspectiva ficou bem evidenciada em dois de seus livros. Um deles intitulava-se Viagem às terras goianas (Brasil central), o qual se referia a uma longa viagem realizada entre 1889 e 1892, na qual ele atravessou o interior do Brasil, visitando-o até o sul, embora a narrativa se concentrasse nas regiões de Goiás e Mato Grosso. Em tal volume a questão do fe- 
minismo já ficava demarcada desde a abertura, em trecho que descrevia a partida de São Paulo por via férrea, momento em que Leal encontrava uma jovem no trem, travando com ela um diálogo, até descobrirem ter algo em comum, ou seja, ambos eram republicanos e feministas (LEAL, 1892, p. 3).

No mesmo livro, mas descrevendo um outro trajeto da viagem, ao sair da capital goiana, Oscar Leal fazia séria censura à forma pela qual eram criadas as moças, dizendo que "as jovens raramente aparecem e vivem ocultas em seus penates". Segundo o autor, era "necessário que a crítica vá desfazendo certos preconceitos para que a mulher deixe de vez esse mutismo que a cerca e se torne apta para todos os arrojos que a natureza a criou". Considerava também que "uma rapariga que é educada de portas a dentro, como freira, que deixa correr numa monotonia enfadonha, os dias da juventude, que evita a sociedade e foge da boa convivência, caminha para o entorpecimento", uma vez que "não é uma senhora é uma coisa qualquer, não será uma esposa, será apenas a mulher propriamente dita, uma massa glutinosa sem consistência, um corpo sem movimento, um espírito sem espírito" (LEAL, 1892, p. 78).

$\mathrm{Na}$ mesma oportunidade, o escritor exemplificava, relatando que "muitas vezes em minhas excursões por vários estados, em lugares e pontos mesmo pouco recônditos, tenho notado que a filha", no seio familiar, "devido ao meio em que vive, procura de preferência a cozinha pela sala, aprecia mais a conversação sensaborona do labrego, do fâmulo ou do camarada, do que a do cavalheiro educado e correto no falar e no trajar". Leal julgava que seria "a bondade paterna que quase sempre se torna culpada destes males". Diante disso, propunha maior liberdade, já que "uma rapariga, que desde os primeiros dias da infância principia a conhecer o mundo, a lançar a vista sobre o bom e o mau, ilustrando-se e desenvolvendo-se, de dia para dia", quando fosse "chegada a hora em que se avizinha do precipício, terá forças, saber e conhecimento para evitá-lo, porque o cultivo da inteligência e a prática da vida fazem-na poder distinguir o visível do aparente". Tratando dos casos contrários a tal orientação, concluía que "outro tanto não sucede à menina tola, inexperiente, sem rudimentos de convivência" (LEAL, 1892, p. 78-79).

Em etapa bem mais adiantada da excursão, Leal referia-se a alguns dos males que julgava como causas dos atrasos no interior brasileiro, apontando que um deles seria o gerado pelo fato de que "os pais não curam da educação de seus filhos", além disso, referia-se à péssima remuneração dos professores. Especificamente a respeito do feminino, enfatizava que "a educação das mulheres em Goiás é coisa em que ninguém cogita", de modo que acabava por restar-lhes como destino, "ler um pouco e mal, fazer crochê, esperar o casório ou ficar para tia.... Referindo-se à intelectual feminista francesa, Anne-Louise Germaine de Staël-Holstein, o autor mais uma vez argumentava que "isso tudo só por culpa dos pais e pela persistência destes em imitar os usos de seus antepassados". Diante disso, pregava que todos deveriam seguir "os conselhos de madame de Stael que julga as mulheres aptas pra todos os arrojos do engenho humano, o que é uma verdade". (LEAL, 1892, p. 136 e 162).

Outro comentário sobre a educação feminina deu-se no livro Viagem a um país de selvagens, no momento em que o escritor descrevia a cidade paraense de Cametá, afirmando que a mesma possuía "cinco escolas públicas e duas particulares". De forma elogiosa, citava uma instituição específica vol- 
tada à formação educacional feminina, referindo-se à escola "dirigida por uma filha do senhor coronel M., cavalheiro distintíssimo e chefe de uma família modelo", na qual "as meninas recebem luz e instrução, sobretudo conselhos de civilidade, conhecimento sobre o modo de simples dicção, segundo tive ensejo de observar" (LEAL, 1895, p. 36). Interessante observar que, apesar do enaltecimento à iniciativa, o nome da responsável pela casa de ensino não foi lembrado, havendo apenas a identificação a partir da paternidade. Poderia ser uma omissão proposital de parte do escritor, por alguma deferência respeitosa, ou uma simples falha da memória do narrador, ou ainda um ato falho do defensor do feminismo.

A grande manifestação de Oscar Leal em prol da emancipação feminina, expressa em seus livros sobre excursões ao Brasil, aparecia também em Viagem a um país de selvagens, já na parte final da narrativa, retratando o retorno do viajante pelo Pará. Nessa linha, quando passava os "últimos dias em Cametá", localidade na qual ficou por algum tempo, durante o qual ocorreu a fundação de um clube literário. A partir da certa notoriedade que vinha conquistando como homem de letras, naturalista e "doutor-dentista", foi inevitável o convite para que Leal fosse orador em tal inauguração. Uma vez realizado o convite, o escritor, após alguma reflexão, decidiu-se a falar sobre a educação da mulher, ressaltando que o tema despertara "um acolhimento que sempre esperei de tão seleto auditório, mas de que me considero fraco merecedor" (LEAL, 1895, p. 216-217), explicitando uma de suas marcas registradas, a falsa modéstia.

Leal revelava que tal assunto poderia gerar controvérsias, afirmando que sabia "perfeitamente que a franca manifestação de pensamento desperta opiniões e produz, em conjunto, afeiçoados e desafeiçoados". Perante tal circunstância, mostrava-se desafiador, definindo-se como um "daqueles que preferem afrontar as consequências desferidas pela crítica, do que ditá-la a encoberto", pois "os fins benéficos que dela devem provir, solidificar-se-ão melhor, muito melhor, em face do original que a produz". Mais uma vez retomando sua falsa modéstia, Leal dizia que se o seu "mérito é mesquinho e diminuto para fazer realçar o seu valor, a nossa obra foi produzida em céu aberto sem as cores anônimas do costume, que empenam", de modo que "outros mais abalizados, se assim o entenderem, estender-lhe-ão as mãos, dando-lhe apoio e incremento" (LEAL, 1895, p. 217).

Após o introito preparatório, na busca do acolhimento público diante de assunto apontado como tão espinhoso, Oscar Leal explanava sobre as vivências das mulheres no Brasil e suas restritas opções educacionais, dando ênfase ao erro que seria a criação das moças voltadas inteiramente ao casamento. 0 escritor defendia que era "forçoso meditar", de modo a verificar se o matrimônio era o melhor caminho, tanto para a mulher quanto para o homem, de modo a evitar arrependimentos, que poderiam redundar em ódio, não podendo o casório ser fruto apenas da "obediência a um capricho" (LEAL, 1895, p. 219). A partir de tais considerações, Leal realizava uma síntese acerca dos obstáculos que vinham prejudicando a emancipação feminina, mormente aquela movida a partir da educação:

Assim me foi dada ocasião de tratar da educação da mulher, porque para ela deve convergir as vistas de todos os bons patriotas.

É fato sabido e notório que, com raras exceções, a mulher no Brasil recebe uma educação rudimentar e quase sempre demais limitada, representando um papel secundá- 
rio quando a sua inteligência lhe dá direito a vastas aspirações, impelindo-a baldamente a grandes cometimentos. Não podem, porém, atingir o ponto a que se destinam pelos estultos preconceitos que ainda predominam nos nossos meios hipócritas e que conseguem com o aplauso de muitos estorvarlhes os passos.

A nossa sociedade é verdadeiramente estúpida; vivemos cercados de um romantismo impressionável, num todo falso e deleitável ao mesmo tempo.

Uma jovem molda o seu procedimento pelas obras românticas que lê e lhe abrasaram a imaginação, sem lembrar-se de que cai assim num mundo fictício e que se trai a si própria.

Depois os males advindos do donjuanismo introduzido na própria sociedade.

Quantas vezes vemos na rua, nas janelas, nas reuniões, nos passeios e nos teatros, um rapaz com pretensões a galanteador e uma moça com desejos de ser amada, ou ter um namorado, porque isso é moda, entregarem-se a idílios estapafúrdios, em que se descobrem gestos tolos, frases apatetadas, passagens ridículas, tudo originado pelo romanticismo?

E uma moça casa porque julga amar o noivo e ser amada simplesmente! Casa com ele porque é um rapaz bem falador, mas que só diz tolices, que veste bem, mas nada possui, nem profissão, nem saber, nem meios que lhe garantam o futuro da família e daí surge a hora do desengano quase sempre tarde.

Uma mulher enfim logo que nasce, encontra o berço alcatifado de flores e teteias; cresce, ainda menina chamam-lhe bonita pelo galanteio, continua a crescer, mira-se ao espelho a toda a hora e a todo o instante, certa de que na realidade é bonita e não lhe faltarão adoradores; esquece o estudo, deixa as costuras a um canto e vai para a janela namorar. A mucama, tipo de perdição que invade as casas de família, é quem a ajuda e lhe facilita os meios de corresponder-se com os namo- rados, uns toleirões que vivem nas esquinas e que lhes escrevem cartinhas repletas de asneiras e sandices. (LEAL, 1895, p. 217219)

Assim, a literatura de viagem traz consigo olhares que podem ir do conjuntural ao pontual, abrindo espaço para a abordagem do papel da mulher na sociedade visitada, como foi o caso dos relatos da lavra de Oscar Leal. Na escrita dos viajantes, o "eu" manifesta "interesse pela alteridade do mundo natural e social" que o cerca, "enquanto fonte de acumulação de experiências pessoais, consumação de fantasias, realização de desejos e atualização de ilusões" (GIUCCI, 1992, p. 30), de modo que ela "se fundamenta no sujeito que alegadamente protagonizou a experiência da viagem, esses textos tendem a desenvolver-se de modo assumidamente controlado por ele" (RITA, 2007, p. 274). Nessa linha, em seus testemunhos, Leal estabeleceu uma contradição entre sua práxis e o seu discurso, pois, por um prisma reificava a mulher, como uma coisa a ser conquista ou apreciada pela sua aparência e, por outro, promovia a ideia da educação feminina, como caminho para a sua emancipação. Tal incoerência poderia advir de uma visão multifacetada, pela qual não importava a forma que eram tratadas as mulheres, pois, pelo menos para o campo discursivo, era necessário manter a perspectiva do homem moderno, progressista, cientificista e libertário, tendências para as quais a emancipação feminina ficaria plenamente a contento. Por outro lado, o autor poderia efetivamente acreditar naquele ideal emancipacionista, mas, ao mesmo tempo, para sustentar o interesse do público, poderia subverter seus princípios para demonstrar uma feição masculina mais desejável ou esperável em relação aos leitores. Esses são apenas dois dos tantos vieses possíveis para 
observar a contradição em pauta, a qual não deixa de estar em consonância com o enorme conjunto de incongruências e idiossincrasias em grande parte típicas do próprio ser humano.

\section{Referências bibliográficas}

ASSUNÇÃO, P. Literatura de viagem: experiência e comunicação de novas ideias. In: QUINTEIRO, S.; BALEIRO, R. \& SANTOS, I. D. (orgs.). Turistas, viajantes e lugares literários. Faro: Universidade do Algarve, 2016. p. 151-166.

AUGUSTIN, G. Literatura de viagem na época de Dom João VI. Belo Horizonte: Editora da UFMG, 2009.

BLAKE, A. V. A. S. Dicionário bibliográfico brasileiro. Rio de Janeiro: Imprensa Nacional, 1899, v. 5 1900, v. 6.

BELLUZZO, A. M. A propósito d'O Brasil dos viajantes. In: Revista USP, São Paulo, n. 30, p. 8-19, junho/agosto 1996.

GIUCCI, G. Viajantes do maravilhoso: o Novo Mundo. São Paulo: Companhia das Letras, 1992.

LEAL, O. Viagem ao centro do Brasil (impressões). Lisboa: Tipografia Largo do Pelourinho, 1886.

LEAL, O. Viagem às terras goianas (Brasil central). Lisboa: Tipografia Minerva Central, 1892.

LEAL, O. Contos do meu tempo. Recife: Tipogra- fia de José Nogueira de Souza, 1893.

LEAL, O. Viagem a um país de selvagens. Lisboa: Livraria de Antônio Maria Pereira, 1895.

LEAL, O. Dentistas e "dentistas" - crítica (de luva calçada) ao folheto de Francisco Ortiz O Dentista Moderno. Lisboa: Livraria Editora da Viúva Tavares Cardoso, 1904.

PEREIRA, E. \& RODRIGUES, G. Portugal - dicionário histórico, corográfico, biográfico, bibliográfico, heráldico, numismático e artístico. Lisboa: João Romano Torres \& Cia. Editores, 1909. v. 4.

REICHEL, H. J. Relatos de viagens como fonte histórica para estudo de conflitos étnicos na região platina (séc. XIX). In: VÉSCIO, L. E. \& SANTOS, P. B. (orgs.). Literatura \& História: perspectivas e convergências. Bauru: EDUSC, 1999. p. 55-77.

RITA, A. No fundo dos espelhos [II] - em visita. Porto: Caixotim Edições, 2007.

SEIXO, M. A. Entre cultura e natureza: ambiguidades do olhar viajante. In: Revista USP, São Paulo, n. 30, p. 120-133, junho/agosto 1996.

SILVA, I. F. Dicionário bibliográfico português. Lisboa: Imprensa Nacional, 1894, t. 17.

TORRESÃO, G. Oscar Leal. In: GIL BRAZ. Lisboa, 10 maio 1898 , a. 1 , n. 2, p. 1-2.

Recebido em: $17 / 09 / 2020$ Aprovado em: 27/10/2020 